\title{
The Relationship between Ideal L2 Self and Willingness to Communicate Inside the Classroom
}

\author{
Nihan Bursal1 ${ }^{1} \&$ Hüseyin Öz $z^{2}$ \\ ${ }^{1}$ Department of Foreign Language Education, Ufuk University, Ankara, Turkey \\ ${ }^{2}$ Department of Foreign Language Education, Hacettepe University, Ankara, Turkey \\ Correspondence: Hüseyin Öz, Faculty of Education, Department of Foreign Language Education, Hacettepe \\ University, Ankara, Turkey. Tel: 90-312-780-5521
}

Received: July 23, 2017

doi:10.5430/ijhe.v6n4p229
Accepted: August 15, 2017

Online Published: August 21, 2017

URL: https://doi.org/10.5430/ijhe.v6n4p229

\begin{abstract}
Over the past decades there has been a dramatic increase in academic research on motivation to learn a second or foreign language (L2). The present study tried to investigate the relationship between the ideal L2 self as a motivational variable and willingness to communicate in English (L2 WTC) inside the classroom. Participants were 56 university students majoring in English as a foreign language (EFL) at a private university in Ankara, Turkey. Data were collected using the Ideal L2 Self Scale and Willingness to Communicate inside the Classroom Scale. Findings of descriptive statistics indicated that $32.1 \%$ of the participants had high, $30.4 \%$ had moderate, and $37.5 \%$ had low L2 WTC inside the classroom scores. Findings also revealed a significant relationship between these two constructs noticing the relations at a skills specific level. The implications are discussed to present ideas to language teachers, teacher trainers, and curriculum designers to raise their awareness on the impact of ideal L2 self on willingness to communicate.
\end{abstract}

Keywords: Motivation, Ideal L2 self, Willingness to communicate, Communication, EFL learners

\section{Introduction}

Psychology as an academic discipline has long examined human mind both at general and individual level. As part of psychological investigations, individual differences (ID) research comes from research endeavors that focus on human mind at individual level. Within this research, motivation has a crucial place along with many other factors such as language aptitude, learning strategies, and learning styles. Succinctly defined as "the direction and magnitude of learning behavior in terms of the learners' choice, intensity, and duration of learning" (Dörnyei \& Ryan, 2015, p. 6), motivation is a complex construct that has drawn attention of many scholars. Therefore, there has been a shift in motivational research. Currently, the prevailing model of language learning motivation is "L2 Motivational Self System" of Dörnyei $(2005,2009)$, which consists of three components: ideal L2 self," ought to self, and L2 learning experience. It is asserted that the essential impetus in the construction of one's motivation is the gap "between one's current sense of self in L2 and one's ideal L2 self" (Williams, Mercer, \& Ryan, 2016, p. 115).

On the other hand, the notion of willingness to communicate originated within individual differences as a personality trait firstly in L1. However, in accordance with the ultimate aim of second or foreign language teaching, which is the construction of communicative competence or basically to communicate with the target community, this notion became a topic of L2. There has been a great amount of study focusing on the predictors of L2 WTC such as, "extraversion/introversion, anxiety, integrativeness, motivation, international posture, self-confidence" (Yashima, 2012). However, one's perceived communicative competence can be strongly related with one's WTC in EFL contexts, while anxiety is regarded as the most influencial one in immersion environments (Peng \& Woodrow, 2010; Yashima, 2002; Yashima et al. 2004, Yashima, 2012). Therefore, it is suggested that a strong relationship between one's ideal L2 self and WTC is expected in EFL contexts.

The present study is an attempt to investigate the relationship between the ideal L2 self of Dörnyei and Ryan's (2015) L2 motivational self-system and willingness to communicate of people in individual differences research. The previous studies show that some learners can have an adequate level of competence, yet they can stay unwilling and vice versa can occur, too (MacIntyre, 2007; Sert, 2015). As both of them can be included in motivational research, their relationship is an interesting research topic and has been investigated by some scholars such as Munezane 
(2013), Kanat-Mutluoğlu (2016), Öz (2016). Besides, Dörnyei (2005) hypothesized that the relationship between linguistic self-confidence and the ideal L2 self positively influence L2 WTC. However, unlike the previous ones which focused on that notion with generic orientations, the present study focuses on the notion of WTC within a classroom context. It is assumed that the learners' ideas about their future language development and usage can affect their orientation to communication. Therefore, this study aims to understand the relationship between them. Initially, it focuses on the related literature of ideal L2 self and WTC along with the research questions of the study, followed by the research methododology used to investigate the relationship between ideal L2 self and WTC at a skills specific level. The findings of the study and the discussion part are presented in harmony. Ultimately, conclusions, further ideas and limitations of the study are expressed with some implications for EFL contexts.

\section{Literature Review}

\subsection{Ideal L2 Self}

The concept of "self" is one of the most recent research topics in motivational research in educational sciences along with such constructs as self-determination, self-efficacy, self-esteem, self-regulation (Ryan and Dörnyei, 2013). Another framework about selves is "the L2 Motivational Self System" proposed by Dörnyei (2005). It can be said that this construct has been established by synthesizing Markus and Nurius's (1986) "the possible selves theory" and Higgins's (1987) "self-discrepancy theory". Possible selves basically show the individuals' future perceptions "of what they might become, what they would like to become, what they are afraid of becoming" (Markus \& Nurius, 1986, p. 954). Briefly, possible selves are about future beliefs rather than one's current beliefs, experiences or background.

On the other hand, Higgins (1987) proposed "self-discrepancy theory" focusing on how possible selves regulate motivation. This theory consists of the ideal self, the ought to self and the actual self. The first one can be defined as "what one would like to possess ideally". At this point, one can think about hopes, aspirations, and wishes. The ought to self is "what one ought to possess such as duty, obligations or responsibilities". Finally, one's actual self refers to "one's present beliefs at the specific time" (Higgins, 1987, p. 320).

Dörnyei's (2005) framework of the L2 Motivational Self System based on Markus and Nurius's (1986) "the possible selves theory" and Higgins's (1987) "self-discrepancy theory" composed of three aspects, Ideal L2 Self, Ought to Self and L2 Learning Experience. The ideal L2 self is associated with L2 user's beliefs, ideas or/and goals on his or her L2 usage. Namely, it is "the L2-specific facet of one's ideal self" (Dörnyei, 2009, p. 29). In addition, "the gap between the ideal L2 self and one's current level can influence one's motivation in the language learning process" (Dörnyei \& Ryan, 2015, p.87). The ought-to self is associated with L2 user's obligations and duties, or what is expected from the individual in his or her L2 learning process. The L2 learning experience, on the other hand, focuses on L2 learner's present experiences. These experiences can stem from diverse things such as learner's success, failure, and the environment including the L2 teacher, curriculum, etc. (Dörnyei \& Ryan, 2015, p.87-88).

A considerable amount of literature has been published on Dörnyei's framework since it was first introduced (Lamb, \& Chambers, 2013; MacIntyre, MacKinnon, \& Clément, 2009; Murray, 2011; Papi, 2010; Ryan, 2009; Taguchi, Magid, \& Papi, 2009; Yahima 2009). Not only did these studies try to validate the framework of the L2 Motivational Self System but they also investigated it in different contexts and tried to focus on the predictors of the framework.

A review of literature indicates that L2 learners' levels of ideal L2 self could have an impact on their level of motivation due to the association with their proficiency in L2 (Ryan \& Dörnyei, 2013). Furthermore, Dörnyei (2014) suggests that the inadequate level of ideal L2 self can be one of the reasons why somebody does not possess L2 motivation in high levels. Even though, motivation has so many affecting factors, it is claimed that the gap between "one's current sense of self in the L2 and one's ideal L2 self" is the essential impetus to motivation to learn a language both in its initiation and continuation (Williams, Mercer \& Ryan, 2016, p.115). When the impact of ideal L2 self on motivation is taken into consideration, one can assume that there might be a relationship between the ideal L2 self and willingness to communicate as this notion can be regarded as rooted in the motivational research and one of the main parts of language learning when it is associated with communicate competence.

\subsection{Willingness to Communicate}

Having its roots from Individual Differences research, Willingness to Communicate is a complex construct which is conceptualized firstly in L1 (McCroskey \& Baer, 1985; McCroskey \& Richmond, 1987, 1990). It can simply be defined as one's preference to speak without any pressure or something else. Initially, the scholars treated this construct as a personality trait and argued that it is enduring even the situations can differ. In addition, some antecedents have been proposed such as introversion, self-esteem, communicative competence, communication 
apprehension and cultural diversity. To illustrate, McCroskey and Richmond (1990) conducted a comparative study on WTC in the USA, Sweden, Australia, Micronesia and Puerto Rico. The countries may have similarities as Western context outweighed. However, the results are undeniable as they differed among the countries. Therefore, one can assume that WTC is culture dependent.

Shortly after, this construct has been a topic for L2 as it is proper and fruitful especially in line with the notion of communicative competence. However, one's behaviors in L1 and in L2 do not match identically, implying that one's WTC level would differ in L1 and in L2. Consequently, the antecedents will differ, too. In terms of L2 WTC, one should take into account so many factors such as "a specific mode of the student, deeply rooted anxiety, unattractiveness of the topic, his or her ideas of competence, fear of making mistakes or insufficient time to answer" (Williams, Mercer \& Ryan, 2016, p.140). There has been a great deal of research in terms of L2 WTC, yet the most influential one is the pyramid-shaped model proposed by MacIntyre, Clement, Dörnyei, and Noels (1998).

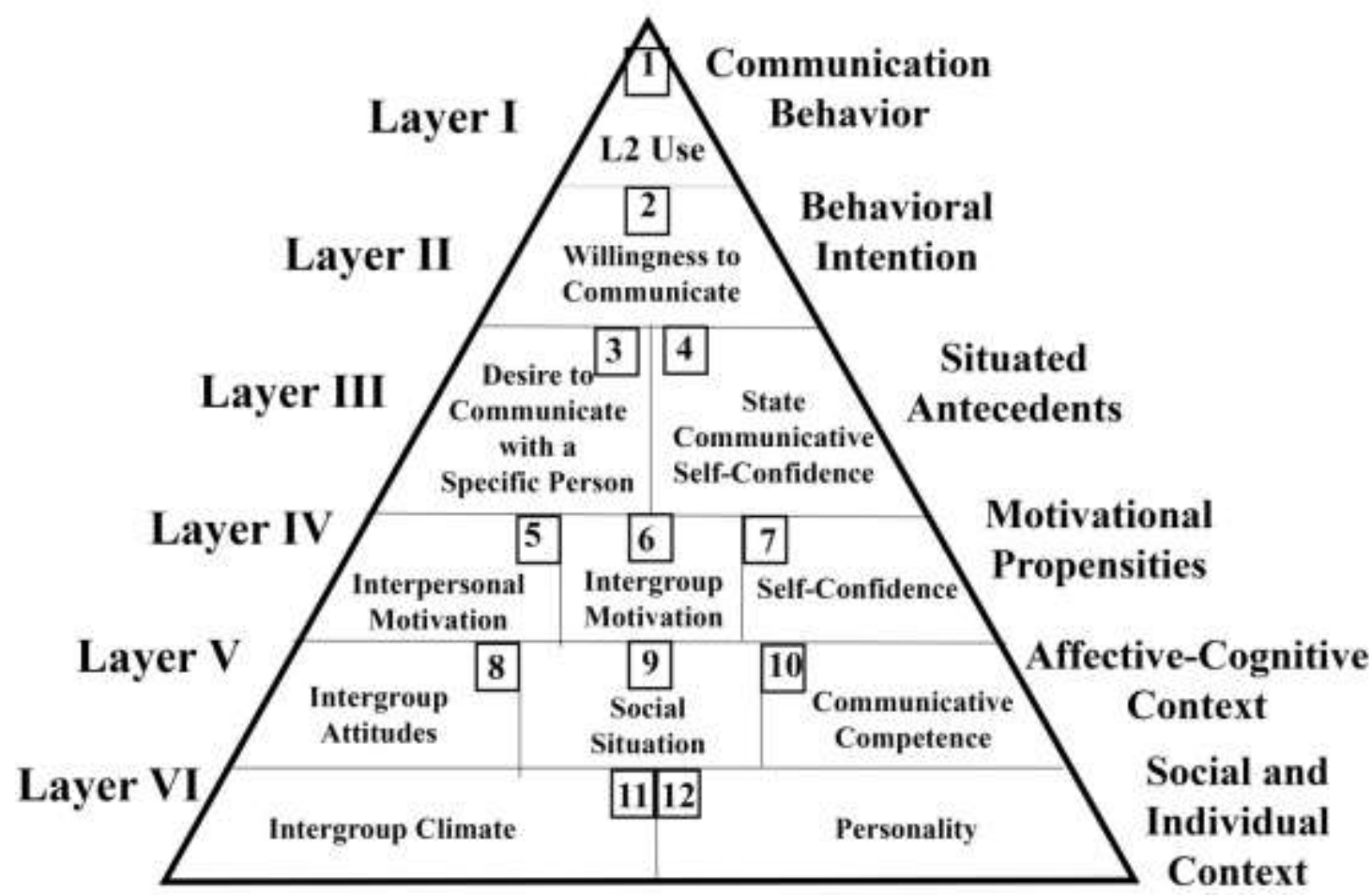

Figure 1. Pyramid shaped L2 WTC Model (MacIntyre et al., 1998)

With this model MacIntre et al. (1998) combined the enduring variables such as personality and more situational variables such as desire to communicate with a specific person. This model has six layers. At the top, there is the actual L2 usage. At the second layer, there is one's intention to communicate with a specific person at a specific time (WTC) which is the last step to start to speak in L2 (MacIntyre et al., 1998) and the layer goes to more enduring antecedents. Namely, at the bottom there is personality and intergroup climate. Although a great amount of research has been done to validate this model, any fixed array of antecedents has not been identified as Ellis mentioned (2008). Therefore, WTC can be a fruitful topic for researchers. Besides, sometimes people do not prefer to talk even though they have an adequate level of competence. This can explain the question why people cannot talk although they have high scores academically.

In recent years, some studies have investigated the predictors of L2 WTC from different angles. For example, Ghonsooly, Fatemi and Khajavy (2013) examined the relation between WTC, communication confidence, and classroom environment as well as EFL learners' level of WTC in English. Similarly, Peng and Woodrow (2010) investigated L2 WTC in relation to self-confidence and classroom environment. On the other hand, Cao $(2011,2014)$ examined L2 WTC with ecological and sociocognitive perspectives. Ghoonsooly, Hoesseini, and Asadpour (2012), MacIntyre and Charos (1996), Öz (2014) examined it in relation to personality traits. In addition, Munezane (2016) investigated motivation, ideal self and willingness to communicate as predictors of observed L2 use in classroom. From these studies it is understood that the notion of WTC has also been under methodological development as the state level WTC is hard to measure with quantitative orientations. Therefore, MacIntyre and Legatto (2011) proposed 
a new methodology called "idiodynamic method" to investigate L2 WTC with its dynamism and it is supported by other scholars (Yashima, 2012).

In line with the aim of the present study, there are some studies that focus on WTC and Ideal L2 self. For instance, Munezane (2010, 2013, 2015) expressed that ideal L2 self had a predictive affect on L2 WTC and these two notions have an affect on actual L2 use. Kanat-Mutluoğlu (2016) found a strong positive correlation between ideal L2 self and WTC. By the same token, Öz (2016) found a positive correlation between these two. In Iranian context, Khajavy and Ghonsooly (2016) examined WTC in reading and their results indicated that L2 motivational self system can adequately account for WTC. However, this construct may differ from one culture to culture and it is still in its infancy and any contribution to the field will be beneficial as one can understand it is a dynamic construct. Moreover, the previous studies focusing on WTC were conducted at the university environment and they used McCroskey's scale (1992). Yet, the present study was conducted with Willingness to Communicate inside the Classroom Scale, constructed by MacIntyre, Baker, Clément, and Conrod (2001). It is claimed that even though McCroskey's (1992) scale was a well-validated instrument for assessing one's general tendency to communicate, there are some problems while analyzing WTC in classroom (Cao\& Philp, 2006; MacIntyre et al., 2001).

The scale has four subcategories in terms of reading, writing, speaking, and comprehension. Therefore, the relationship will be explained with a skills specific perspective. With the help of this scale, unlike the McCroskey's (1992) one can understand about students' classroom based WTC levels. Therefore, one can talk about the situation specific WTC in the classroom environment.

The following research questions were formulated to guide the present study:

1. What are the general scores of students' ideal L2 self and willingness to communicate inside the classroom?

2. Is there any significant difference in students' ideal L2 self and WTC inside the classroom in terms of gender?

3. Is there any significant relationship in terms of ideal L2 self and willingness to communicate inside the classroom?

\section{Method}

\subsection{Research Design}

The present study was conducted with a quantitative research design. Questionnaires were distributed to gather the data about the participants' demographic background such as gender, age and their perceived levels of the ideal L2 self and willingness to communicate inside the classroom.

\subsection{Setting and Participants}

The present study was conducted in a pre-service EFL teacher education program at a private university in Turkey in the spring semester of 2016-2017 academic year. A total of 56 EFL learners majoring in English as a foreign language program voluntarily participated in the study and gave consent for data collection. The participants ranged in age from 18 to $26(M=20.59$ years, $S D=1.64)$. The surveys were anonymous, and without any consultation, among themselves, they completed the questionnaires during the class hours. Table 1 and Table 2 show the gender and age distributions of participants.

Table 1. The gender distribution of the participants

\begin{tabular}{llllll}
\hline Variable & Gender & $\mathrm{N}$ & Mean & SD & $\%$ \\
\hline Gender & Male & 18 & - & - & 32 \\
& Female & 38 & & & 68 \\
\hline
\end{tabular}


Table 2. The age distribution of the participants

\begin{tabular}{llllll}
\hline Variable & Ages & $\mathrm{N}$ & Mean & SD & $\%$ \\
\hline Age & 18 & 2 & & 3.6 \\
19 & 9 & & 16.1 \\
20 & 23 & 20.59 & 1.64 & 41.1 \\
21 & 12 & & 21.4 \\
22 & 4 & & 7.1 \\
& 23 & 1 & & 5.4 \\
& 25 & 2 & & 1.8 \\
& 26 & & & 3.6 \\
\hline
\end{tabular}

\subsection{Instruments}

\subsubsection{Willingness to Communicate inside the Classroom}

The Willingness to Communicate inside the Classroom Scale (MacIntyre et al., 2001) was used to understand the students' perceived level of WTC in classroom context. It is a 27-item 5-point Likert scale which consists of 5 subscales: reading, writing, speaking, and comprehension. The participants were asked to indicate the frequency that they may choose to be willing to communicate in those specific situations from 1 to 5 (1=almost never willing, $2=$ sometimes willing, $3=$ willing half of the time, $4=$ usually willing, $5=$ almost always willing). The internal consistency of the scale was $\alpha=.83$.

\subsubsection{Ideal L2 Self}

The Ideal L2 Self Measure (Dörnyei \& Taguchi, 2010) was employed to identify the participants' levels of ideal L2 self. This measure is a 5-point Likert scale consisting of 10 items. The participants were asked to indicate their agreement to the items from 1 to $5(1=$ strongly disagree, $2=$ disagree, $3=$ neither agree nor disagree, $4=$ agree, $5=$ strongly agree). The internal consistency of the scale was $\alpha=.86$ in the present study.

\subsection{Procedures for Data Collection and Analysis}

This study was conducted in a preservice EFL teacher education program at a private university in Turkey It took participants around fifteen minutes on average to complete the surveys. Data drawn from the participants were fed into the computer and statistical analyses were conducted using IBM SPSS 21 statistical package, a comprehensive computer program used to help researchers perform statistical analysis quickly and accurately. Descriptive statistics such as frequency, percentages and mean were computed to understand the participants' ideal L2 self and willingness to communicate inside the classroom levels. The independent samples T- test was conducted to find out if there was any significant difference in terms of gender. By taking into account the main purpose of the study and its limitations, age factor, and the participants' GPAs were intentionally excluded from the study. In addition, due to the nonparametric distribution of ideal L2 self data, the Spearsman correlation coefficients were computed to explore the relationship between the ideal L2 self and willingness to communicate inside the classroom.

\section{Findings and Discussion}

For the first research question, the descriptive statistics for willingness to communicate inside the classroom $(M=3.77$, $S D=.47)$ and ideal L2 self $(M=4.29, S D=.55)$ is given below in Table 3. As given, $32.1 \%$ of the participants had high, $30.4 \%$ had moderate, and $37.4 \%$ had low WTC inside the classroom scores. These findings can be regarded as unsatisfactory as the participants are majoring in English language teaching program. In addition, these findings differed from the previous ones', such as Öz (2016) found that 38\% of the participants had high L2 WTC, 43\% had moderate L2 WTC, and 19\% had low L2 WTC and Öz, Demirezen and Pourfeiz's (2015). However, the scores of WTC and ideal L2 self are compatible. As given, 25\% of the participants had high ideal L2 self, $35.7 \%$ had moderate and $39.3 \%$ had low ideal L2 self scores. 
Table 3. Descriptive statistics for WTC inside the classroom and ideal L2 self

\begin{tabular}{llll}
\hline Variable & Rank & F & $\%$ \\
\hline Willingness to Communicate Inside the Classroom & High & 18 & 32.1 \\
& Moderate & 17 & 30.4 \\
& Low & 21 & 37.4 \\
Ideal L2 self & High & 14 & 25.0 \\
& Moderate & 20 & 35.7 \\
& Low & 22 & 39.3 \\
\hline
\end{tabular}

The descriptive statistics including scale items for WTC inside the classroom is also given below at Table 4. As one can see the respondents' indication of the most willing situation is "understand an English movie" and the least willing situation is "write a newspaper article."

Table 4. Descriptive statistics of WTC inside the classroom including scale items

\begin{tabular}{|c|c|c|c|c|c|}
\hline Statements & $\mathbf{N}$ & Minimum & Maximum & Mean & SD \\
\hline Write a newspaper article. & 56 & 1 & 5 & 3.02 & 1.300 \\
\hline How willing would you be to be an actor in a play? & 56 & 1 & 5 & 3.09 & 1.493 \\
\hline 3. Read an article in a paper. & 56 & 1 & 5 & 3.21 & 1.275 \\
\hline 4. Write an advertisement to sell an old bike. & 56 & 1 & 5 & 3.29 & 1.155 \\
\hline Write down a list of things you must do tomorrow. & 56 & 1 & 5 & 3.39 & 1.139 \\
\hline 6. Write a story. & 56 & 1 & 5 & 3.46 & 1.190 \\
\hline 7. Speaking to your teacher about your homework assignment & 56 & 0 & 5 & 3.50 & 1.027 \\
\hline 8. Listen to instructions and complete a task. & 56 & 1 & 5 & 3.59 & 1.092 \\
\hline $\begin{array}{l}\text { 9. A stranger enters the room you are in, how willing would } \\
\text { you be to have a conversation if he talked to you first? }\end{array}$ & 56 & 2 & 5 & 3.63 & 1.071 \\
\hline $\begin{array}{l}\text { 10. Read an advertisement in the paper to find a good bicycle } \\
\text { you can buy. }\end{array}$ & 56 & 1 & 5 & 3.64 & 1.257 \\
\hline 11. Fill out an application form. & 56 & 1 & 5 & 3.64 & .923 \\
\hline 12. Read a novel. & 56 & 0 & 5 & 3.66 & 1.325 \\
\hline 13. Speaking in a group about your summer vacation & 56 & 1 & 5 & 3.86 & 1.069 \\
\hline 14. Bake a cake if instructions were in English. & 56 & 1 & 5 & 3.88 & 1.192 \\
\hline 15. Write the answers to a 'fun' quiz from a magazine. & 56 & 1 & 5 & 3.89 & 1.090 \\
\hline $\begin{array}{l}\text { 16. You are confused about a task you must complete, how } \\
\text { willing are you to ask for instructions/clarification? }\end{array}$ & 56 & 1 & 5 & 3.91 & 1.116 \\
\hline 17. Take directions from an English speaker. & 56 & 1 & 5 & 3.91 & .978 \\
\hline 18. Write a report on your favorite animal and its habits. & 56 & 1 & 5 & 3.91 & 1.164 \\
\hline $\begin{array}{l}\text { 19. Read personal letters or notes written to you in which the } \\
\text { writer has deliberately used simple words and } \\
\text { constructions. }\end{array}$ & 56 & 2 & 5 & 3.96 & .873 \\
\hline 20. Play a game in English, for example Monopoly. & 56 & 1 & 5 & 4.00 & 1.062 \\
\hline 21. Write a letter to a friend. & 56 & 1 & 5 & 4.00 & 1.009 \\
\hline 22. Describe the rules of your favorite game. & 56 & 1 & 5 & 4.05 & .923 \\
\hline 23. Talking to a friend while waiting in line. & 56 & 2 & 5 & 4.13 & .810 \\
\hline 24. Read reviews for popular movies. & 56 & 1 & 5 & 4.13 & 1.028 \\
\hline 25. Write down the instructions for your favorite hobby. & 56 & 2 & 5 & 4.29 & .825 \\
\hline 26. Read letters from a pen pal written in native English. & 56 & 3 & 5 & 4.39 & .731 \\
\hline 27. Understand an English movie. & 56 & 2 & 5 & 4.54 & .713 \\
\hline
\end{tabular}

The descriptive statistics for each item is also given below in Table 5. As one can see the scores seem high, yet it is 
expected as the students are enrolled in ELT program their ideal selves about L2 is relatively high. The highest item is "The things I want to do in the future require me to use English", again they probably will be English teachers; therefore, it is quite expected. However, the lowest item is "I can imagine myself speaking English as if I were a native speaker of English".

Table 5. Descriptive statistics of ideal L2 self including items

\begin{tabular}{|c|c|c|c|c|c|}
\hline Statements & $\mathrm{N}$ & Minimum & Maximum & Mean & SD \\
\hline $\begin{array}{l}\text { 1. I can imagine myself speaking English as if I were a } \\
\text { native speaker of English. }\end{array}$ & 56 & 2 & 5 & 3.96 & 1.061 \\
\hline $\begin{array}{l}\text { 2. I can imagine myself studying in a university where all } \\
\text { my courses are taught in English. }\end{array}$ & 56 & 1 & 5 & 4.00 & .991 \\
\hline $\begin{array}{l}\text { 3. I imagine myself writing English e-mails/letters } \\
\text { fluently. }\end{array}$ & 56 & 1 & 5 & 4.07 & .931 \\
\hline $\begin{array}{l}\text { 4. I can imagine myself living abroad and having a } \\
\text { discussion in English. }\end{array}$ & 56 & 1 & 5 & 4.18 & .855 \\
\hline $\begin{array}{l}\text { 5. Whenever I think of my future career, I imagine myself } \\
\text { using English. }\end{array}$ & 56 & 2 & 5 & 4.29 & .780 \\
\hline $\begin{array}{l}\text { 6. I can imagine myself speaking English with } \\
\text { international friends and colleagues. }\end{array}$ & 56 & 2 & 5 & 4.38 & .799 \\
\hline $\begin{array}{l}\text { 7. I can imagine myself living abroad and using English } \\
\text { effectively for communicating with locals. }\end{array}$ & 56 & 2 & 5 & 4.38 & .776 \\
\hline $\begin{array}{l}\text { 8. I can imagine a situation where I am speaking English } \\
\text { with foreigners. }\end{array}$ & 56 & 2 & 5 & 4.52 & .660 \\
\hline $\begin{array}{l}\text { 9. I imagine myself as someone who is able to speak } \\
\text { English. }\end{array}$ & 56 & 3 & 5 & 4.54 & .602 \\
\hline $\begin{array}{l}\text { 10. The things I want to do in the future require me to use } \\
\text { English. }\end{array}$ & 56 & 2 & 5 & 4.64 & .699 \\
\hline
\end{tabular}

For the second question to understand if there is any significant difference between male and female students in terms of WTC inside the classroom, an independent samples T-test was conducted which is given at Table 6. The results revealed that there was statistically no significant difference in terms of gender. As for WTC inside the classroom $\mathrm{t}(95)=1.29, \mathrm{p}>.05$. Even though the male scores are higher than female scores, their ratings did not translate into the statistical difference between groups. These results are against to previous studies such as Öz's (2016) who found higher female scores. However, both of them are statistically non-significant.

Table 6. Group statistics for gender differences in WTC inside the classroom and ideal L2 self

\begin{tabular}{lllll}
\hline & Gender & N & Mean & SD \\
\hline \multirow{2}{*}{ WTC inside the classroom } & male & 18 & 3.89 & .43 \\
& female & 38 & 3.72 & .48
\end{tabular}

Ideal L2 self

$\begin{array}{llll}\text { male } & 18 & 4.44 & .43 \\ \text { female } & 38 & 4.22 & .59\end{array}$

Furthermore, an independent samples T-test was conducted to determine if there was a significant difference between males and females in terms of their ideal L2 self. The findings revealed that there was no statistically significant difference, $\mathrm{t}(95)=1.40, \mathrm{p}>.05$, between males and females regarding their perceptions of ideal $\mathrm{L} 2$ self. These findings are compatible with Öz's (2016). However, they are against to Azarnoosh and Birjandi's (2012) who found small 
significant result pointing that females have higher scores than males in terms of ideal L2 self.

To sum up, these results show that males $(\mathrm{M}=3.89, \mathrm{SD}=.43)$ are more willing to communicate inside the classroom than females $(\mathrm{M}=3.72, \mathrm{SD}=.48)$. In terms of the participants' future perceptions of ideal L2 self, again male's $(\mathrm{M}=$ $4.44, \mathrm{SD}=.43)$ scores are higher than female's $(\mathrm{M}=4.22, \mathrm{SD}=.59)$ scores.

For the third question related to the relationship between WTC inside the classroom and Ideal L2 self, the distribution of normality of the scores was first assessed. Since the distribution was nonparametric, the Spearsman Correlation coefficients were calculated to analyze the relationship between ideal L2 self and WTC (Table 7).

Table 7. Spearsman Correlation Matrix for Ideal L2 self and WTC inside the classroom

\begin{tabular}{llllll}
\hline & 1 & 2 & 3 & 4 & 5 \\
1 Ideal L2 self & - & & & \\
2 Speaking &. $\mathbf{4 8 7}^{* *}$ & - & & \\
3 Reading & $\mathbf{. 4 3 1}^{* *}$ & .197 & - & \\
4 Writing & $\mathbf{. 5 4 8}^{* *}$ & $.309^{*}$ & $.540^{* *}$ & - \\
5 Comprehension & $\mathbf{. 5 6 5}^{* *}$ & $.273^{*}$ & $.563^{* *}$ & $.554^{* *}$ & - \\
& & & & & \\
& & & &
\end{tabular}

The relationships between ideal L2 self and willingness to communicate inside the classroom with subcategories are given above and they are all positively correlated. Furthermore, the correlations are significant at the .01 level. According to results, the highest correlation with ideal L2 self and willingness to communicate is on comprehension with .565 . Writing follows with .548 and speaking follows with .487. The lowest correlation is on reading with .431.

\section{Conclusions}

The main aim of the study was to investigate the relationship between ideal L2 self and willingness to communicate inside the classroom. The relations were positive and highly significant. As mentioned at the findings part, comprehension or we can say listening had the highest point writing, speaking and reading followed it, respectively. To my knowledge, there is not any similar study in terms of its sub categorical focus. However, there are some studies focused on WTC and Ideal L2 self (Munezena, 2013; Kanat-Mutluoğlu, 2016; Öz, 2016) which are in line with this present one.

In addition, it was found that the participants had relatively lower levels of L2 WTC when compared to previous studies. At that point, one needs to consider that the present study was conducted in a private university and these findings should be taken into consideration by private institutions. Furthermore, the academicians working in private institutions may try to raise their students' awareness on WTC, as a strong relationship was found between WTC and ideal L2 self, it can be claimed that ideal L2 self can contribute the students' willingness to communicate in English. Therefore, it is possible to have an impact on students' motivation and can enhance the students' perceptions of communication. These findings have theoretical and pedagogical implications for language teachers, teacher trainers, and curriculum designers.

With theoretical eyes, the findings simply advocate the application of L2 motivational self system in Turkish context. Therefore, the transformation from traditional motivational models to process- oriented L2 motivational self system and substitution of integrative motivation with ideal L2 self. On the other hand, from the pedagogical perspective, it is important to know that the students' high WTC promotes their language learning process. With the help of previous studies, it is known that there are more than one antecedents of L2 WTC, such as introversion, self-esteem, communicative competence, communication apprehension, and so on. Likewise, it is undeniable that a specific mode of the student, deeply rooted anxiety, unattractiveness of the topic, his or her ideas of competence, fear of making mistakes or insufficient time to answer may affect one's L2 WTC. In addition, the present findings point the impact of ideal L2 self on L2 WTC. With all these knowledge, a teacher should not be overwhelmed; yet, needs to take them into consideration while constructing one's communication skills or willingness to communicate (Williams, Mercer \& Ryan, 2016).

In EFL settings, such as Turkey the students do not have a direct interaction with the target community. However, 
English is taught at schools, universities and other educational institutions. Even though the students' WTC is associated with the students' academic achievement, sometimes the students may prefer to stay silent. Therefore, to raise the students' negotiation in the classroom is a part of the teachers' duty. In the light of the findings, it is suggested that the teachers need to work on the strategies that can enhance the students' perceptions of ideal L2 self; thus, their linguistic self-confidence will enhance, their motivation will enhance and ultimately their desire to communication or willingness to communicate will enhance.

The present study examined the relationship between ideal L2 self and L2 WTC. Yet, the ideal L2 self is one of the components of L2 motivational self system. For further research, one may want to include all of the components and investigate these two notions with complexity; thus, can make broader judgments about the relationship between L2 motivational self system and WTC. Lastly, due to the total of 56 respondents and it was conducted in Turkish context, generalizations should be handled with caution and further studies are required with larger samples either in quantitative or in qualitative manner to make better judgments on the relationship between L2 motivational self system and WTC.

\section{References}

Azarnoosh, M., \& Birjandi, P. (2012). Junior high school students' L2 motivational self system: Any gender differences. World Applied Sciences Journal, 20(4), 577-584.

Cao, Y. (2011). Investigating situational willingness to communicate within second language classrooms from an ecological perspective. System, 39(4), 468-479. https://doi.org/10.1016/j.system.2011.10.016

Cao, Y. K. (2014). A sociocognitive perspective on second language classroom willingness to communicate. TESOL Quarterly, 48(4), 789-814. https://doi.org/10.1002/tesq.155

Dörnyei, Z. (2005). The psychology of the language learner: Individual differences in second language acquisition. Mahwah, NJ: Lawrence Erlbaum. https://doi.org/10.1177/0261927X05281424

Dörnyei, Z. (2009). The L2 motivational self system. Motivation, language identity and the L2 self, 36(3), 9-11.

Dörnyei, Z. (2014). Motivation in second language learning. In M. Celce-Murcia, D. M.Brinton, \& M. A. Snow (Eds.), Teaching English as a second or foreign language (pp. 518-531). Boston, MA: National Geographic Learning/Cengage Learning.

Dörnyei, Z., \& Ryan, S. (2015). The psychology of the language learner revisited. London: Routledge.

Dörnyei, Z., \& Taguchi, T. (2010). Questionnaires in second language research: Construction, administration, and processing (2nd ed.). London: Routledge.

Ellis, R. (2008). The study of second language acquisition (2nd ed.). Oxford: Oxford University Press.

Ghonsooly, B., Khajavy, G. H., \& Asadpour, S. F. (2012). Willingness to communicate in English among Iranian non-English major university students. Journal of Language and Social Psychology, 3, 197-211. https://doi.org/10.1177/0261927X12438538

Ghonsooly, B., Fatemi, A. H., \& Khajavy, G. H. (2013). Examining the relationships between willingness to communicate in English, communication confidence, and classroom environment. International Journal of Research Studies in Educational Technology, 3(1), 63-72. https://doi.org/10.5861/ijrset.2013.392

Higgins, E. T. (1989). Self-discrepancy theory: What patterns of self-beliefs cause people to suffer? Advances in experimental social psychology, 22, 93-136. https://doi.org/10.1016/S0065-2601(08)60306-8

Islam, M., Lamb, M., \& Chambers, G. (2013). The L2 motivational self system an national interest: A Pakistani perspective. System, 4l(2), 231-244. https://doi.org/10.1016/j.system.2013.01.025

Kanat-Mutluoğlu, A. (2016). The influence of ideal 12 self, academic self-concept and intercultural communicative competence on willingness to communicate in a foreign language. Eurasian Journal of Applied Linguistics, 2(2), $27-46$.

Khajavy, G. H., \& Ghonsooly, B. (2017). Predictors of willingness to read in English: testing a model based on possible selves and self-confidence. Journal of Multilingual and Multicultural Development, 1-15. https://doi.org/10.1080/01434632.2017.1284853

MacIntyre, P. D., \& Charos, C. (1996). Personality, attitudes, and affect as predictors of second language communication. Journal of Language and Social Psychology, 15, 3-26. https://doi.org/10.1177/0261927X960151001 
MacIntyre, P. D., Baker, S. C., Clément, R., \& Conrod, S. (2001). Willingness to communicate, social support, and language-learning orientations of immersion students. Studies in second language acquisition, 23(03), 369-388. https://doi.org/10.1017/S0272263101003035

MacIntyre, P. D., Dörnyei, Z., Clément, R., \& Noels, K. A. (1998). Conceptualizing willingness to communicate in a L2: A situational model of L2 confidence and affiliation. The Modern Language Journal, 82(4), 545-562. https://doi.org/10.1111/j.1540-4781.1998.tb05543.x

MacIntyre, P. D., \& Legatto, J. J. (2011). A dynamic system approach to willingness to communicate: Developing an idiodynamic method to capture rapidly changing affect. Applied Linguistics, 32(2), 149-171. https://doi.org/10.1093/applin/amq037

MacIntyre, P. D., MacKinnon, S. P., \& Clément, R. (2009). The baby, the bathwater, and the future of language learning motivation research. In Z. Dörnyei \& E. Ushioda (Eds.), Motivation, language identity and the L2 self (43-65). Bristol, UK: Multilingual Matters.

Magid, M., \& Chan, L. (2012). Motivating English learners by helping them visualize their Ideal L2 Self: Lessons from two motivational programmes. Innovation in Language Learning and Teaching, 6(2), 113-125. https://doi.org/10.1080/17501229.2011.614693

Markus, H., \& Nurius, P. (1986). Possible selves. American Psychologist, 41(9), 954-969. https://doi.org/10.1037/0003-066X.41.9.954

McCroskey, J. C., \& Baer, J. E. (1985). Willingness to communicate: The construct and its measurement. Paper presented at the annual convention of the Speech Communication Association, Denver.

McCroskey, J. C., \& Richmond, V. P. (1987). Willingness to communicate. Personality and Interpersonal Communication, 6, 1-11.

McCroskey, J. C., \& Richmond, V. P. (1990). Willingness to communicate: Differing cultural perspectives. Southern Journal of Communication, 56(1), 72-77. https://doi.org/10.1080/10417949009372817

McCroskey, J. C. (1992). Reliability and validity of the willingness to communicate scale. Communication Quarterly, 40(1), 16-25. https://doi.org/10.1080/01463379209369817

Munezane, Y. (2010). The power of will to pass the Rubicon: A way to foster WTC. Paper presented at Doctoral Workshop, EUROSLA Conference 20, University of Modena and Reggio Emilia, Reggio Emilia, Italy.

Munezane, Y. (2013). Attitudes, affect and ideal L2 self as predictors of willingness to communicate. EUROSLA Yearbook, 13(1), 176-198. https://doi.org/10.1075/eurosla.13.09mun

Munezane, Y. (2015). Enhancing willingness to communicate: Relative effects of visualization and goal setting. The Modern Language Journal, 99(1), 175-191. https://doi.org/10.1111/modl.12193

Murray, G. (2011). Imagination, metacognition and the L2 self in a self-access learning environment. In G. Murray, X. Gao \& T. Lamb (Eds.), Identity, motivation and autonomy in language learning (75-90). Clevedon, UK: Multilingual Matters.

Williams, M., Mercer, S., \& Ryan, S. (2016). Exploring psychology in language learning and teaching. Oxford University Press.

Öz, H. (2014). Big Five personality traits and willingness to communicate among foreign language learners in Turkey. Social Behavior and Personality: An International Journal, 42(9), 1473-1482. https://doi.org/10.2224/sbp.2014.42.9.1473

Öz, H. (2016). Role of the ideal L2 self in predicting willingness to communicate of EFL students. In I. J. Mirici, I. H. Erten, H. Öz, and I. Vodopija-Krstanović (Eds.), Research papers on teaching English as an additional language (pp. 163-182), Rijeka, Croatia: Faculty of Humanities and Social Sciences, University of Rijeka.

Öz, H., Demirezen, M., \& Pourfeiz, J. (2015). Willingness to communicate of EFL learners in Turkish context. Learning and Individual Differences, 37, 269-275. https://doi.org/10.1016/j.lindif.2014.12.009

Papi, M. (2010). The L2 motivational self system, L2 anxiety, and motivated behavior: A structural equation modeling approach. System, 38(3), 467-479. https://doi.org/10.1016/j.system.2010.06.011

Peng, J. E., \& Woodrow, L. (2010). Willingness to communicate in English: A model in the Chinese EFL classroom context. Language learning, 60(4), 834-876. https://doi.org/10.1111/j.1467-9922.2010.00576.x 
Ryan, S. (2009). Self and identity in L2 motivation in Japan: The ideal L2 self and Japanese learners of English. In Z. Dörnyei \& E. Ushioda (Eds.), Motivation, language identity and the L2 self (pp.120-143). Clevedon, UK: Multilingual Matters.

Ryan, S., \& Dörnyei, Z. (2013). The long-term evolution of language motivation and the L2 self. Fremdsprachen in der Perspektive leben slangen Lernens, 89-100.

Sert, O. (2015). Social interaction and L2 classroom discourse. Edinburgh: Edinburgh University Press.

Taguchi, T., Magid, M., \& Papi, M. (2009). The L2 motivational self system among Japanese, Chinese and Iranian learners of English: A comparative case study. In Z. Dörnyei \& E. Ushioda (Eds.), Motivation, language identity and the L2 self (pp. 66-97). Clevedon, UK: Multilingual Matters.

Yashima, T. (2002). Willingness to communicate in a second language: The Japanese EFL context. The Modern Language Journal, 86(1), 54-66. https://doi.org/10.1111/1540-4781.00136

Yashima, T. (2009). International posture and the ideal L2 self in the Japanese EFL Context. In Z. Dörnyei \& E. Ushioda (Eds.), Motivation, language identity and the L2 self. (pp.144-163). Clevedon, UK: Multilingual Matters.

Yashima, T. (2012). Willingness to communicate: Momentary volition that results in L2 behaviour. In S. Mercer, S. Ryan, \& M. Williams (Eds.), Psychology for language learning (pp. 119-135). Hampshire, UK: Palgrave Macmillan.

Yashima, T., Zenuk- Nishide, L., \& Shimizu, K. (2004). The influence of attitudes and affect on willingness to communicate and second language communication. Language Learning, 54(1), 119-152. https://doi.org/10.1111/j.1467-9922.2004.00250.x 